\title{
The Factors that Influence the Community Preference Using Financial Technology Services in Sharia Financial Institutions
}

\author{
Ahmad Aziz Putra Pratama ${ }^{1}$. \\ ${ }^{1}$ Master of Science in Management, Department of Management, \\ Faculty of Economics and Business, Universitas Airlangga \\ Jl. Airlangga No. 4-6, Surabaya 60286, Indonesia \\ *azizputra@gmail.com
}

DOI: https://doi.org/10.22219/jes.v5i1.11533

Check for updates

\begin{tabular}{ll}
\hline & \multicolumn{1}{c}{ ABSTRACT } \\
\cline { 2 - 3 } $\begin{array}{l}\text { Kata Kunci: } \\
\text { Fechnolal }\end{array}$ & This research aims to investigate the factors that influence community \\
Financial & preference in using financial technology services in sharia financial \\
Inculsion; & multitions. This research uses a descriptive quantitative method through \\
Sharia & Rembang people who unse sharia fintech services with 1,171 respondents. \\
Tsarnsaction. & $\begin{array}{l}\text { The sample is selected through incidental sampling. The results show that } \\
\text { perceived ease, perceived benefit, and attitude influence the community } \\
\text { preference using financial technology services in sharia financial } \\
\text { institutions. }\end{array}$ \\
\hline
\end{tabular}

Article Info:

Submitted:

01/11/2019

Revised:

16/01/2020

Published:

25/02/2020

How to cite: Putra, A. A. P. (2020). The Factors that Influence the Community Preference Using Financial Technology Services in Sharia Financial Institutions. Falah: Jurnal Ekonomi Syariah, 5(1), 15-24. doi. https://doi.org/10.22219/jes.v5i1.11533 


\section{INTRODUCTION}

Indonesia had the biggest account ownership increase in the region as the number increased from 20 percent in 2011, to 36 percent in 2014 and 49 percent in 2017 (World Bank, 2018). In 2018, the number of active smartphone users in Indonesia is more than 100 million people. With such a large number, Indonesia will become the fourth-largest smartphone user in the world after China, India, and America (Ministry of Communication and Information Technology [MOCIT], 2015). While the internet user population of the country reaches 123 million people in 2018 (MOCIT, 2014).

In Indonesia, around 75 percent of the online buys are made through cellphones. (DBS, 2018). The growth of the number of internet users and the use of cellphones can be used as a consideration by financial institutions in developing their services tailored to society's development (Kurniawan, 2013). Currently, cellphones are not only used as a means of communication but also to perform online financial services, such as bill payments, account transfer, person-to-person transfer, proximity payments at the point of sale, long-distance payments to buy goods and services, and other types of services such as location-based, cellular marketing, tickets, discounts or coupons (Oliveira, Thomas, Baptista, \& Campos, 2016). One of the services that has been developed by the banking sector is an online banking system. (Irmadhani, 2012). As of 2014, around 8 percent of the population aged 15 or more used debit cards for purchasing, grew to 11 percent in 2017 (Demirguc-Kunt et al., 2018). The recent changes have seen the country experience a flourishing entry and growths of the financial technology (fintech) platforms and companies. While there has yet to be a formal definition for the fintech itself, Dorfleinter et al. (2017)

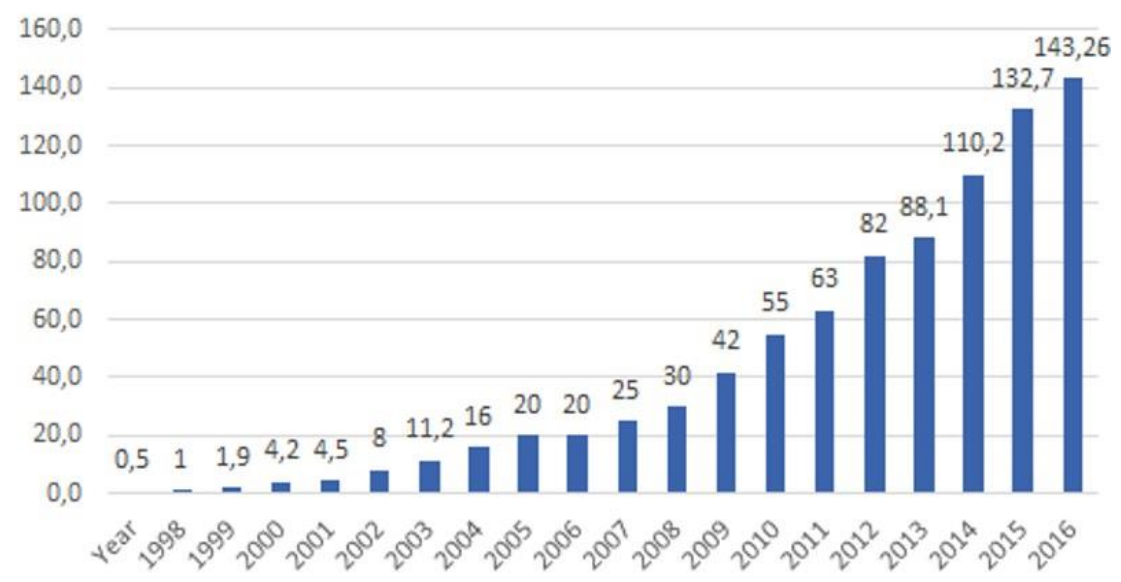

Figure 1. Internet Users in Indonesia (in millions)

Source: APJII (2017) 
Previous research have argued that perceived ease has a significant effect on the interest Liébana-Cabanillas et al. (2014), Kurniawan (2013), Amalia (2018), and Gunawan (2014). While perceived benefits significantly influence the interest of community in using financial technology de Kerviler, Demoulin, \& Zidda (2016), Kurniawan (2013), Amalia (2018), and Gunawan (2014). On the other hand, the attitude influence people's intention according to their beliefs Liébana-Cabanillas, Sánchez-Fernández, \& Muñoz-Leiva, (2014), Suyanto \& Kurniawan (2019), Kurniawan (2013), and Lorenzo et al. (2011).

However, there have been no previous studies that have conducted research related to customer satisfaction in relation to the community preference using financial technology services in sharia financial institutions. This paper presents to analyze the factors that influence community preference in using financial technology services in sharia financial institutions.

\section{RESEARCH METHOD}

The method used in this research is quantitative descriptive with the population of Rembang people who had savings in sharia financial institutions. The sampling technique was incidental sampling that is based on coincidence in which anyone who accidentally or incidentally meets with the researcher can be used as a sample if he is considered suitable as a data source. In collecting data using questionnaires, samples obtained were 1,171 respondents. the independent variables used in this study are Perceived Ease, Perceived Benefit, and Attitude. This study used a quantitative method with multiple linear regression analysis techniques. Multiple linear regressions are explained through several stages of testing including validity, reliability, normality and classic assumptions for the feasibility study model which then tested the hypothesis using partial and simultaneous tests with the following regression equation:

$$
F U I_{i, t}=\beta_{0}+\beta_{1} P E_{i, t}+P B_{i, t}+A T_{i, t}+\varepsilon_{i, t}
$$

Technology Acceptance Model (TAM) considers that the two main behavioral variables in adopting information systems are the usefulness and ease of use. The benefit user perceptions are defined as the rate at which a person believes that using a particular system can improve his performance, and the ease of using internet banking is defined as the level at which someone believes that using a system does not require much effort. The ease of using internet banking also influences user perceptions of the benefits which can also be interpreted that if people feel that a system is easy to use, the system is useful for them (Wijayanti, 2011).

E-banking is a type of flexible service since it can be used to help customers do financial transactions anywhere and anytime. A wide opportunity to enter the market for 
this type of mobile banking service is a challenge for the banking industry to explore the factors that affect customers prefer to use e-banking (Kurniawan, 2013).

Dependent variable used this research is a person's behavior depends on one's attitude about behavior and subjective norms. When someone intends to do a particular behavior, it is possible that he will do that behavior. This study used four independent variable that consist of perceived ease, perceived benefit and attitude.

Perceived ease (PE) means the belief that the system is useful at any time and facilitates transactions, services can be understood, speed of access. PE indicator consists of easiness to perform, reliability and the easiness to install the application of ebanking services (Wijaya, 2006).

While, perceived benefit ( $\mathrm{PB})$, the degree at which someone believes that using a particular system can improve its performance, effective, the linkage. In short, the extent to which benefits can be felt by users in using technology systems. PB consists of flexibility (time \& place), help customers in doing their tasks, and faster transaction process.

While Attitude (AT), attitude is developed over time when someone gets to experience. Attitudes are considered as multidimensional constructs consisting of cognitive, emotional, and conative dimensions or behavior. The feeling of 'profitable' or 'unprofitable' towards certain behaviors reflects an attitude (Fishbein, 1963), where it shows that attitudes are developed in a time when someone gets to experience. However, different theoretical models (TAM, TRA, and TPB) have found that attitude is an important prerequisite in the intention to develop a particular behavior (Ajzen, 1980). A study revealed that the attitude of Fintech software users had a positive effect on the interest in using the software (Suyanto \& Kurniawan, 2019). Attitudes are considered as multidimensional constructs, which consist of dimensions of cognitive, emotional, and conative or behavior (Fishbein \& Ajzen, 1975). Individual knowledge about a product or service (experience, trust and opinion) is driven by the cognitive component, while individual preferences about the given object (feelings, emotions, and evaluations) and ultimately driven by emotional components, and behavioral intentions (purchase intention, purchase response, and rejection responses) are conative components (Alonso, 2004).

From the sample collection obtained 1.171 respondents, consist of $54.31 \%$ men and $45.69 \%$ women. The age of respondents are $25-30$ years (31.22\%), 31-35 years (24.19\%), 36-40 years (28.78\%), and above 40 years (6.81\%). Meanwhile, respondents' occupation status are students (31.18\%), self-employed $(37.13 \%)$, and private employees (37.09\%). Data processing of this study shows the determination coefficient of $66 \%$ of the regression model. Testing of data validity shows valid data with the average of robtained is more than rtable and the reliable obtained rtable (one-tailed) 
Vol. 5 No. 1 (2020)

ISSN (print): 2502-3918 | ISSN (online): 2502-7824

value $=0.1817$ which is higher than robtained value of each variable. Based on this, it can be concluded that the data is valid. While for reliability, it can be seen from the value of Cronbach's Alpha $=0.917>0.6$, thus the variables are reliable.

\section{RESULT AND DISCUSSION}

Based on partial testing results between Perceived Ease and Interest using fintech in Table 1, found that significant value is $0.008<0.01$, in which means that $\mathrm{H} 0$ is rejected and $\mathrm{H} 1$ is accepted. Thus, it can be concluded that there is a significant effect between Perceived Ease and Interest using fintech. The coefficient value of perceived ease is 0.311 in Table 1 , the interest in fintech services is 0.311 or $31.1 \%$ if the perception of public convenience increases by one unit. Accordingly, there is a significant influence between Perceived Benefit and Interest in using e-banking services ( $\mathrm{H} 0$ is rejected and $\mathrm{H} 1$ is accepted), it shows that the higher the perceived benefit, the higher the interest in using e-banking services in Rembang. The use of the services depends on the ease of access or ease of service features. In choosing a sharia financial institution that will be used as a place to have saving or financing, community considers a sharia financial institution that has fintech services which are easily accessible at any time and the features of the services can be used in everyday life. This result in line with Liébana-Cabanillas et al. (2014), Kurniawan (2013), Amalia (2018), and Gunawan (2014) who stated that perceived ease has a significant effect on the interest.

Table 1. Panel Data Regression Test Result

\begin{tabular}{|c|c|c|}
\hline Dependent variable: & FUI (Interest in Using Fintech) & \\
\hline Regression: & Multiple Linear Regression & \\
\hline Analysis model: & (1) & \\
\hline \multirow[t]{2}{*}{ Intercept } & & $* 1.911$ \\
\hline & & $(0.081)$ \\
\hline \multirow[t]{2}{*}{ PE (Perceived Ease) } & & $* * * 0.311$ \\
\hline & & (0.008) \\
\hline \multirow[t]{2}{*}{ PB (Perceived Benefit) } & & $* * * 0.381$ \\
\hline & & $(0.002)$ \\
\hline \multirow[t]{2}{*}{ AT (Attitude) } & & $* * * 0.292$ \\
\hline & & $(0.001)$ \\
\hline
\end{tabular}




\begin{tabular}{lr}
\hline & $\mathbf{( 0 . 0 0 0 )}$ \\
\hline Observations & 1,171 \\
R-Squared & 0.412 \\
\hline
\end{tabular}

From Table 1, also shows that there is a significant influence between the Perceived Benefit and Interest in using e-banking services. Coefficient value of perceived benefit is 0.381 and that of the interest in fintech services is 0.381 or $38.1 \%$. The results show that the higher the perceived benefit, the higher the interest in using ebanking services in Rembang.

The benefits of fintech services felt by users are the reason for using fintech services in everyday life. For example, for users who are familiar with online shopping, they will feel the benefits in using fintech services in sharia financial institutions. Community perceived benefit viewed from the usefulness of each service is to be effective and efficient in conducting transactions. The results of this study are in line with de Kerviler, Demoulin, \& Zidda (2016), Kurniawan (2013), Amalia (2018), and Gunawan (2014) who stated that perceived benefits significantly influence interest.

Based on the result of testing between Attitude and Interest using fintech, Table 2 shows that significant value is 0.001 which means that there is a significant influence between attitudes and interest in using e-banking services ( $\mathrm{H} 0$ is rejected and $\mathrm{H} 1$ is accepted), From coefficient value of attitude is 0.292 and that of interest in fintech services is 0.292 or $29.2 \%$. The results of the study show that the attitude of the user after getting experience from other people, seeing other people using the service will attract others to use e-banking services in Rembang.

The coefficient value of the perceived benefit is more dominant to influence interest in using digital services. Community Interest Users of fintech Islamic financial services are influenced by information obtained from other users, the experiences of other users that make them confident to use the fintech services. In addition, the attitude of the public who are curious about the technology of lambaga sharia financial services at this time which is a trend in making transactions makes customers interested in using the fintech services of the Islamic financial institutions. The results of this study support other research by Liébana-Cabanillas, Sánchez-Fernández, \& Muñoz-Leiva, (2014), Suyanto \& Kurniawan (2019), Kurniawan (2013), and Lorenzo et al. (2011) that attitude will influence people's intention according to their beliefs.

In the development of era 4.0 today, it requires innovation from sharia financial institutions to compete in the financial market. Innovation is realized by providing online services for banking members, without neglecting the fact that not all members use technology-based financial technology (fintech). To find out whether the market shares are right or not, several factors influence community perception on fintech of 
Vol. 5 No. 1 (2020)

ISSN (print): 2502-3918 | ISSN (online): 2502-7824

sharia financial institutions which are convenience, benefits, and attitude. Overall, perceived benefit is a major factor in using fintech.

\section{CONCLUSION}

The results show that perceived ease, perceived benefit towards and attitude influence the community preference in using financial technology services in sharia financial institutions Simultaneously, these independent variables will affect one's perceptions in using fintech services because each element of the variable is interrelated and if combined will affect more someone's interest in using digital services. Also, from the coefficient result, something that is more dominant is based on the perception of service benefits of 0.284 in which the people use fintech based on the benefits obtained from the use of theses services. While Regression model of this study resulted in the coefficient of determination of 0.412 . Then the dependent variable can be explained if the independent variable is $41.2 \%$, and the rest is explained if other variables are outside the model.

However further research, it is expected to use a wider coverage of research sample. The limitation of this study is that the scope of the research is only the fintech M-banking service and the sample taken is only the perception of Rembang community. The results of this study recommend sharia financial institutions to improve service innovations that provide convenience, benefits for customers which ultimately will attract the interest of prospective customers to become customers of sharia financial institutions. In addition to that, enhancing security from the use of fintech could make customers loyal to sharia financial institutions.

\section{REFERENCES}

Ajzen, I. (1980). Understanding Attitudes and Predicting Social Behavior. London: Prentice Hall International.

Alonso, J. (2004). Comportamiento del Consumidor. Decisiones y Estrategias de Marketing (5th ed.). Madrid: ESIC.

Amalia, S. N. A. (2018). Faktor-Faktor yang Mempengaruhi Minat Individu terhadap Financial Technology (Fintech) Syariah (Paytren) Sebagai Salah Satu Alat Transaksi Pembayaran: Pendekatan Technology Acceptance Model (TAM) dan Theory of Planned Behavior (TPB). Iqtishaduna, 8(1), 57-73. Retrieved From http://Journal.Uinmataram.Ac.Id/Index.Php/Iqtishaduna/Article/View/687

APJII. (2016). Laporan Survei APJII 2016: Penetrasi dan Perilaku Pengguna Internet Indonesia. Retrieved from https://apjii.or.id/content/read/39/264/SurveiInternet-APJII-2016

APJII. (2017). Laporan Survei APJII 2017: Penetrasi dan Perilaku Pengguna Internet Indonesia. Retrieved from https://apjii.or.id/content/read/39/342/ Hasil-Survei- 
Penetrasi-dan-Perilaku-Pengguna-Internet- Indonesia-2017

Bank Indonesia. (2013). Financial Technologies (Fintech). Retrieved form https://www.bi.go.id/id/sistem- pembayaran/fintech/contents/default.aspx

Bank Indonesia. (2017). Innovation \& Fintech Development in Retail Payment System in Indonesia. Retrieved from https://www.bi.go.id/id/institute/kegiatan/ Flagship/Contents/Day4 Session3 Innovation\%20and\% 20Fintech\%20Dev\%20in\%20Indonesia.pdf?Mobile=1

Bank Indonesia. (2014). Digital Financial Inclusion in Indonesia. Retrieved from https://www.ojk.go.id/id/berita-dan-kegiatan/publikasi/

Documents/Pages/Materi-OJK-PROKSI-2016/7.Digital\%

20Financial\%20Inclusion\%20-\%200JK.pdf

Chandra, S., Srivastava, S. C., \& Theng, Y. L. (2010). Evaluating the Role of Trust in Consumer Adoption of Mobile Payment Systems: An Empirical Analysis. Communications of the Association for Information Systems, 27, 561-588. Retrieved from http://Aisel.Aisnet.Org/Cais/Vol27/Iss1/29

Davis, F. D. (1989). Perceived Usefulness, Perceived Ease of Use, and User Acceptance of Information Technology. MIS Quarterly, 13(3), 319. https://doi.org/10.2307/249008

DBS Bank Group Research (2019). Telecommunication (Indonesia). Retrieved from https://www.dbs.com/ telecommunications indonesia.xml

De Kerviler, G., Demoulin, N. T. \& Zidda, P. (2016). Adoption of in-store Mobile Payment: Are Perceived Risk and Convenience the Only Drivers?. Journal of Retailing and Consumer Services, 31, 334-344. https://doi.org/10.1016/j.jretconser.2016.04.011

Demirguc-Kunt, A., Klapper, L., Singer, D., Ansar, S., \& Hess, J. (2018). The Global Findex Database 2017: Measuring Financial Inclusion and the Fintech Revolution. The World Bank. Retrieved from http://documents.worldbank.org/curated/en/332881525873182837/The-GlobalFindex-Database-2017-Measuring-Financial-Inclusion-and-the-FintechRevolution

Financial Service Authority. (2019). Statistics IKNB. Retrieved form https://www.ojk.go.id/id/kanal/iknb/data-dan-statistik/statistik$\mathrm{iknb/pages/statistik-iknb-periode-desember-2018---revisi.aspx}$

Fishbein, M. (1963). An Investigation of the Relationships Between Beliefs about An Object and the Attitude Toward that Object. Human Relations, 16, 233-239. https://doi.org/10.1177/001872676301600302

Fishbein, M., \& Ajzen, I. (1975). Belief, Attitude, Intetion, an Behavior: an Introduction to Theory and Research. Addison-Wesley: Reading, MA.

Gu, J.C., Lee, S.C., \& Suh, Y. H. (2009). Determinants of Behavioral Intention to Mobile Banking. Expert Systems with Applications, 36(9), 11605-11616. https://doi.org/10.1016/j.eswa.2009.03.024

Gunawan, A. (2014). Aplikasi Technology Acceptance Model Pada Minat Nasabah untuk Menggunakan Internet Banking. Nominal, 3(2), 55-74. https://doi.org/10.21831/nominal.v3i2.2695 
Vol. 5 No. 1 (2020)

ISSN (print): 2502-3918 | ISSN (online): 2502-7824

Irmadhani. (2012). Pengaruh Persepsi Kebermanfaatan, Persepsi Kemudahan Penggunaan dan Computer Self Efficacy, terhadap Penggunaan Online Banking Pada Mahasiswa S1 Fakultas Ekonomi Universitas Negeri Yogyakarta. Kajian Pendidikan Akuntansi Indonesia, 1(3), 1-20. Retrieved from https://journal.uny.ac.id/index.php/jkpai/article/view/882

Kang, J. (2018). Mobile Payment in Fintech Environment: Trends, Security Challenges, and Services. Human-Centric Computing and Information Sciences, 8(1), 32-40. https://doi.org/10.1186/s13673-018-0155-4

Kurniawan, D. (2013). Analisis Penerimaan Nasabah Terhadap Layanan Mobile Banking dengan Menggunakan Pendekatan Technology Acceptance Model dan Theory of Reasoned Action. Jurnal Startegi Pemasaran, 1(1), 1-13. Retrieved from http://publication.petra.ac.id/index.php/manajemenpemasaran/article/view/67

Liébana-Cabanillas, F., Sánchez-Fernández, J., \& Muñoz-Leiva, F. (2014). Antecedents of The Adoption of The New Mobile Payment Systems: The Moderating Effect of Age. Computers in Human Behavior, 35, 464-478. https://doi.org/10.1016/j.chb.2014.03.022

Mayer, R. C., Davis, J. H., \& Schoorman, F. D. (1995). An Integrative Model of Organizational Trust. The Academy of Management Review, 20(3), 709-734. https://doi.org/10.2307/258792

Oliveira, T., Thomas, M., Baptista, G., \& Campos, F. (2016). Mobile Payment: Understanding the Determinants of Customer Adoption and Intention to Recommend the Technology. Computers in Human Behavior, 61, 404-414. https://doi.org/10.1016/j.chb.2016.03.030

Rogers, E. M. (2003). Diffusion of Inovations. New York: Free Press.

Slade, E. L., Dwivedi, Y. K., Piercy, N. C., \& Williams, M. D. (2015). Modeling Consumers' Intentions Adoption of Remote Mobile Payments in the United Kingdom: Extending UTAUT with Innovativeness, Risk, and Trust. Psychology \& Marketing, 32(8), 860-873. https://doi.org/10.1002/mar.20823

Stewart, H. \& Jürjens, J. (2018). Data Security and Consumer Trust in Fintech Innovation in Germany. Information and Computer Security, 26(1), 109-128. https://doi.org/10.1108/ICS-06-2017-0039

Suyanto, S., \& Kurniawan, T. A. (2019). Faktor yang Mempengaruhi Tingkat Kepercayaan Penggunaan Fintech Pada UMKM dengan Menggunakan Technology Acceptance Model (TAM). Akmenika, 16(1), 175-186. Retrieved from https://journal.upy.ac.id/index.php/akmenika/article/view/166

Wijaya, S. W. (2006). Theoretical Study of the Technology Acceptance Model for Model Approach to Determine Willingness Strategies Encourage Users in Using Information and Communication Technology. Proceedings of the Conference on Information Systems.

Rinrin Y., Silviana P., \& Aulia Z. H. K., (2019). The society's perceptions on the use of fintech services in sharia financial institutions. Jurnal Ekonomi dan Keuangan Islam (JEKI), 5(1), 87-92. https://doi.org/10.20885/jeki.vol5.iss2.art6

Wijayanti, R. (2011). Analisis Technology Acceptance Model (TAM) terhadap Faktor- 
Faktor yang Mempengaruhi Penerimaan Nasabah terhadap Layanan Internet Banking (Studi Empiris terhadap Nasabah Bank di Depok). Proceeding of Psychology, Economics, Literature, Architecture and Civil Conference, Universitas Gunadarma, 4, 121-127. Retrieved from https://www.researchgate.net/publication/264888175 